\title{
The Proper Application of Civil RICO to Patent Fraud
}

\author{
Steven Fasman
}

In Sedima, S.P.R.L. v. Imrex Co., ${ }^{1}$ the Supreme Court acknowledged and refused to curb the increasing ${ }^{2}$ use of the powerful civil action provision $^{3}$ of the Racketeer Influenced and Corrupt Organizations Act ${ }^{4}$ (RICO or the Act) by commercial plaintiffs in ordinary business fraud cases. ${ }^{5}$ The Court's interpretation of RICO may have a potentially disastrous side effect, however, because its application will allow the ever-expanding class that claims fraud in the procurement of a patent ${ }^{6}$ to assert a RICO treble damages claim as well. ${ }^{7}$ By altering the carefully balanced set of incentives the patent law creates for inventors, RICO will discourage both invention and patenting. RICO and the law of patent fraud must be construed to avoid these consequences. The regulatory scheme in the patent laws should remain the basic method of patent oversight and control, and only persons who violate the terms of the patent "contract" through willful and highly material fraud should be liable under RICO. Presently, such people may also be liable under the antitrust laws for their frauds.

1. 105 S. Ct. 3275 (1985), decided along with American Nat'l Bank \& Trust Co. of Chicago v. Haroco, Inc., 105 S. Ct. 3291 (1985) (per curiam).

2. The Court noted the large increase in the number of cases adjudicated under the civil action provision, 18 U.S.C. $\S 1964$ (c) (1982). Sedima, 105 S. Ct. at 3277 n.1.

3. 18 U.S.C. $\S 1964$ (c) (1982). Section 1964(c) provides for treble damages, attorney's fees, and costs. Id.

4. 18 U.S.C. $\S \S 1961-1968$ (1982 \& Supp. III 1985). RICO formed Title IX of the Organized Crime Control Act of 1970, Pub. L. No. 91-452, 84 Stat. 922, 941-48.

5. The Court reversed the holding of the Second Circuit, 741 F.2d 482 (2d Cir. 1984), which had tried to limit RICO's growth in the area of business fraud. See also Alexander Grant \& Co. v. Tiffany Indus., 742 F.2d 408 (8th Cir. 1984) (limiting RICO but distinguishing its method from that of Second Circuit's Sedima opinion), vacated and remanded, 105 S. Ct. 3550 (1985). The Sedima dissenters also wished to limit RICO. See infra note 115 and accompanying text.

6. See infra note 49.

7. If the fraud is advanced by use of the mails, the patent applicant may have committed mail fraud. 18 U.S.C. $\S 1341$ (1982); see infra Section II.D. Mail fraud is a RICO predicate act. See infra notes 17-22 and accompanying text.

8. See, e.g., Grant v. Raymond, 31 U.S. (6 Pet.) 218, 241-42 (1832) (describing character of contract); see also Comment, Inequitable Conduct and the Duty of Disclosure in Patent Procurement, 1986 B.Y.U. L. REv. 149, 149 (same). 


\section{The Broad Reach of Givil RICO}

\section{A. The RICO Act}

Congress enacted RICO in $1970^{\circ}$ to provide a remedy against the organization of criminal elements into economic entities of unfair power. ${ }^{10}$ Fearing that sophisticated leaders of organized crime ventures would circumvent any narrowly drawn statute, Congress framed RICO very broadly and included a highly unusual provision mandating that RICO "be liberally construed to effectuate its remedial purposes."11 The bill that became RICO was originally drafted as a criminal statute, ${ }^{12}$ but Congress added a private right of action for civil enforcement against RICO violators analogous to one in antitrust law. ${ }^{13}$ Motivated by the availability of treble damages for all injuries to their business or property caused by a violation of the Act, ${ }^{14}$ costs, and a reasonable attorney's fee, ${ }^{15}$ civil plaintiffs have imaginatively and aggressively invoked RICO in many unexpected areas. ${ }^{16}$

9. See supra note 4 .

10. Sedima, S.P.R.L. v. Imrex Co., 105 S. Ct. 3275, 3299-301 (1985) (Marshall, J., dissenting) (reviewing history of RICO enactment). The statute's purpose is implicit in its title, $i d$, at 3288 (Powell, J., dissenting), as well as the legislative history. See, e.g., H.R. REP. No. 1549, 91st Cong., 2d Sess. 185, reprinted in 1970 U.S. Code Cong. \& ADMIN. News 4007, 4081 (dissenting views of Reps. Conyers, Mikva, and Ryan) (RICO "seeks to stymie organized crime's growing infiltration of legitimate business"); S. REP. No. 617, 91st Cong., 1st Sess. 35-46 (1969) (discussing organized crime problem in United States); id. at 76 (purpose of Title IX is "elimination of the infiltration of organized crime and racketeering into legitimate organizations operating in interstate commerce"); id. at 80 (Title IX will remove organized crime from its sources of economic power); see also United States v. Turkette, 452 U.S. 576, 589 (1981) ("purpose of Congress "to seek the eradication of organized crime in the United States'" (quoting statement of findings prefacing Organized Crime Control Act of 1970, 84 Stat. 922, 923 (1970), reprinted in 18 U.S.C. $\S 1961$ app. at 362 (1982)).

11. Organized Crime Control Act of 1970, Pub. L. No. 91-452, § 904(a), 84 Stat. 922, 947, reprinted in 18 U.S.C. \$ 1961 app. at 362 (1982); see Russello v. United States, 464 U.S. 16, 27 (1983) (RICO is "only substantive federal criminal statute that contains such a directive").

12. See Sedima, $105 \mathrm{~S}$. Ct. at $3280-81$, and sources cited therein.

13. Id.; id. at 3282 \& n.8. But see the cautionary note in id. at 3297-99 (Marshall, J., dissenting) (explaining dangers of inferring too much from analogy). Cf. Clayton Act $\S 4,15$ U.S.C. $\S 15$ (1982) (civil action provision of antitrust laws).

14. Section 1962 is the heart of RICO. Subsection (a) makes it a crime for a person to use or invest income derived from a pattern of racketeering activity to acquire an interest in, establish, or operate any "enterprise" that is engaged in or affects interstate or foreign commerce. 18 U.S.C. $\S$ 1962(a) (1982). An "'enterprise' includes any individual, partnership, corporation, association, or other legal entity, and any union or group of individuals associated in fact although not a legal entity." 18 U.S.C. \& 1961(4) (1982). Subsection 1962(b) makes it a crime "for any person thraugh a pattern of racketeering activity ... to acquire or maintain ... any interest in or control of any enterprise which is engaged in, or the activities of which affect, interstate or foreign commerce." 18 U.S.C. $\S 1962$ (b) (1982). The next subsection declares it to be "unlawful for any person employed by or associated with any enterprise engaged in, or the activities of which affect, interstate or foreign commerce, to conduct or participate . . . in the conduct of such enterprise's affairs through a pattern of racketeering activity . . .."18 U.S.C. $\$ 1962$ (c) (1982). Finally, it is illegal to conspire to do any of the above. 18 U.S.C. $\S 1962$ (d) (1982).

15. 18 U.S.C. $\$ 1964$ (c) (1982).

16. See, e.g., cases collected infra note 89; Bank of Am. Nat'l Trust \& Sav. Ass'n v. Touche Ross \& Co., 782 F.2d 966 (11th Cir. 1986) (bank audit error); Furman v. Cirrito, 741 F.2d 524 (2d Cir. 
RICO plaintiffs must allege that the defendant conducted an enterprise through a "pattern of racketeering activity,"17 defined to require at least two of a listed set of chargeable or indictable "predicate" acts committed within ten years of each other. ${ }^{18}$ These predicate acts include mail and wire fraud, ${ }^{19}$ and extortion or interference with commerce. ${ }^{20}$ The fraud offenses, sources of much of RICO's growth, prohibit criminally fraudulent schemes that involve use of the mails or wires, ${ }^{21}$ and each such use is a separately indictable act. ${ }^{22}$ Hence two mailings can turn simple liability for the tort of fraud into potentially crippling exposure to treble damages.

1984), vacated and remanded sub nom. Joel v. Cirrito, 105 S. Ct. 3550 (1985) (partnership dissolution).

17. 18 U.S.C. $\S 1962$ (1982).

18. 18 U.S.C. $\$ 1961(5)(1982)$ provides:

(5) "pattern of racketeering activity" requires at least two acts of racketeering activity, one of which occurred after the effective date of this chapter and the last of which occurred within ten years (excluding any period of imprisonment) after the commission of a prior act of racketeering activity.

"Racketeering activity" is defined at 18 U.S.C. $§ 1961$ (1) (Supp. III 1985) by expressly listing a large set of state and federal criminal activities.

19. 18 U.S.C. $\S 1341$ (1982) provides in pertinent part:

Whoever, having devised or intending to devise any scheme or artifice to defraud, or for obtaining money or property by means of false or fraudulent pretenses, representations, or promises ... for the purpose of executing such scheme or artifice or attempting so to do, places in any post office or authorized depository for mail matter, any matter or thing whatever to be sent or delivered by the Postal Service, or takes or receives therefrom, any such matter or thing, or knowingly causes to be delivered by mail according to the direction thereon, or at the place at which it is directed to be delivered by the person to whom it is addressed, any such matter or thing, shall be fined not more than $\$ 1,000$ or imprisoned not more than five years, or both.

18 U.S.C. $\$ 1343$ (1982) provides:

Whoever, having devised or intending to devise any scheme or artifice to defraud, or for obtaining money or property by means of false or fraudulent pretenses, representations, or promises, transmits or causes to be transmitted by means of wire, radio, or television communication in interstate or foreign commerce, any writings, signs, signals, pictures, or sounds for the purpose of executing such scheme or artifice, shall be fined not more than $\$ 1,000$ or imprisoned not more than five years, or both.

The two statutes are to be construed in pari materia. United States v. Lemire, 720 F.2d 1327, 1334 n.6 (D.C. Cir. 1983), cert. denied, 467 U.S. 1226 (1984); United States v. Giovengo, 637 F.2d 941, 944 (3d Cir. 1980), cert. denied, 450 U.S. 1032 (1981). Henceforth this Note will use "mails" to refer to both the mails and the wires, and $\S 1341$ to refer to both $\S 1341$ and $\S 1343$.

20. 18 U.S.C. $\S 1951$ (1982) provides in relevant part:

(a) Whoever in any way or degree obstructs, delays, or affects commerce or the movement of any article or commodity in commerce, by robbery or extortion or attempts or conspires so to do, or commits or threatens physical violence to any person or property in furtherance of a plan or purpose to do anything in violation of this section shall be fined not more than $\$ 10,000$ or imprisoned not more than twenty years, or both.

(b) As used in this section...

(2) The term "extortion" means the obtaining of property from another, with his consent, induced by wrongful use of actual or threatened force, violence, or fear, or under color of official right.

This Note will not examine the specific impact of a RICO claim based on $\S 1951$ on the patent law though many of the same policy considerations apply. For the mechanics of such a claim, see Adamo \& Ducatman, Civil RICO-Are Patents Next?, 66 J. PAT. Off. Soc'y 185, 231-32 (1984).

21. See infra Section I.B. (analyzing mail fraud statute).

22. "[T]here is no doubt that the law may make each putting of a letter into the post office a 
The courts have confirmed the broad reach of RICO. For example, the enterprise associated with the racketeering activity may be either "legitimate" or "illegitimate."23 In Sedima, the Court held that a civil plaintiff could initiate an action against a defendant who had never been convicted either of RICO or of predicate criminal violations, ${ }^{24}$ nor need a plaintiff allege a separate "racketeering" injury beyond the harms caused by the predicate acts. ${ }^{25}$ The Court felt compelled to interpret broadly the statute because of its language and part of its accompanying legislative history, even though this construction implicitly sanctions suits in areas never contemplated by Congress. ${ }^{28}$

\section{B. Common Law Fraud and the Federal Mail and Wire Fraud Statutes}

The growth of civil RICO derives in large measure from the inclusion of mail fraud within the definition of racketeering activity. ${ }^{27}$ The scope of criminal liability for mail fraud has grown startlingly, and the crime is now far removed from the original concept of actionable fraud. ${ }^{28}$ Even so, common law fraud rules provide a useful basis for comparison that aids understanding regarding the reach of the statute.

separate offence." " United States v. Joyce, 499 F.2d 9, 18 (7th Cir.) (quoting Badders v. United States, 240 U.S. 391, 394 (1916)), cert. denied, 419 U.S. 1031 (1974).

According to a former Chief of Business Frauds Prosecutions for the United States Attorney for the Southern District of New York, the legal fiction that the act of mailing is the core of the crime of mail fraud has several unusual consequences, including the fact that

it results in each separate use of the mails constituting a separate crime. Consequently, the number of counts of mail fraud with which a defendant may be charged turns not on the scope or duration of the fraud, the number of victims, the amount of damage, or any other factor relating to the moral culpability of the perpetrator or the social damage inflicted by his fraud, but rather depends on the sheer happenstance of how many times the mails have been used in executing the fraud.

Rakoff, The Federal Mail Fraud Statute (Part I), 18 DuQ. L. REv. 771, 778 (1980) (footnote omitted).

23. United States v. Turkette, 452 U.S. 576 (1981).

24. 105 S. Ct. 3275, 3284 (1985).

25. Id. at 3285 .

26. Id. at 3286-87. For the announced purpose of Congress, see supra note 10 and accompanying text.

27. A 1985 study found that of the 270 civil RICO cases known at that time, $77 \%$ principally involved claims of fraud. RePort of THE Ad Hoc Civil RICO TASK Force of THE ABA SECTION of Corporation, Banking and Business Law 55-56 (1985), cited in Sedima, 105 S. Ct. at 3287 n.16; see also Oversight on Civil RICO Suits: Hearings Before the Senate Comm. on the Judiciary, 99th Cong., 1st Sess. 126-27 (1985) [hereinafter 1985 Hearings] (statement of Stephen S. Trott, Ass't Att'y Gen.) (citing Justice Department statistics). But see id. at 423-25 (statement of Nat'l Ass'n of Att'ys Gen. and Nat'l Dist. Att'ys Ass'n) (challenging ABA Report figures).

28. It is difficult to ascertain whether Congress intended that any "scheme or artifice to defraud" prohibited by the statute, see supra note 19 , also create liability as a common law tort, because neither the original enactment nor any subsequent revision had any useful legislative history. See Morano, The Mail-Fraud Statute: A Procrustean Bed, 14 J. Marshall L. Rev. 45, 45-47 \& n.2 (1980). The courts have never held that the statute only prohibits conduct that would create liability in tort. See infra note 30 and accompanying text. 
Proof of common law fraud required (1) an affirmative misrepresentation (2) of a material fact (3) made with knowledge of its falsity (4) and with intent to deceive (5) upon which another relied (6) to her actual injury. ${ }^{29}$ The federal courts have required less for mail fraud ${ }^{30}$ and have simplified and otherwise reduced the elements of the crime. The two principal elements are a scheme to defraud and a use of the mails. ${ }^{31}$ The scheme may consist of omissions of material facts or otherwise deceptive patterns of conduct as well as affirmative misrepresentations. ${ }^{32}$ Courts do not require proof that anyone is actually taken in by the deception ${ }^{33}$ or that the scheme otherwise succeeds in any way. ${ }^{34}$ Hence reliance and injury are not elements of the federal offense. Although most circuits require a scheme reasonably calculated to defraud persons of " "ordinary prudence and comprehension," "ss some courts have held that a violation occurs even if only the most gullible people will be deceived. ${ }^{38}$

Courts also differ on the requisite level of intent. Although a specific intent to defraud is always necessary, ${ }^{37}$ some courts have held that this intent may be demonstrated by a "reckless disregard" of the facts, ${ }^{38}$ while others hold that "knowledge"si is required. Misrepresentations that form

29. See Prosser and Kfeton on the Law of Torts 727-29 (W. Keeton 5th ed. 1984); 37 C.J.S. Fraud § 3 (1943); Restatement (SECOND) of ToRTs \$§ 525-549 (1977); see also American Hoist \& Derrick Co. v. Sowa \& Sons, Inc., 725 F.2d 1350, 1363-64 (Fed. Cir.) (distinguishing common law fraud from patent fraud), cert. denied, 469 U.S. 821 (1984).

On the problems of proof in fraud cases, see A. LefF, Swindling and Selling 181-83 (1976).

30. See Rakoff, supra note 22, at 799 \& nn.117-18; see also Durland v. United States, 161 U.S. 306 (1896) (rejecting defense based on necessary elements of common law tort of false pretenses).

31. Pereira v. United States, 347 U.S. 1, 8-9 (1954) (elements of mail fraud are scheme to defraud and mailing of letter to execute scheme); United States v. Haimowitz, 725 F.2d 1561, 1568-69 (11th Cir.), cert. denied, 469 U.S. 1072 (1984).

32. United States v. O'Malley, 707 F.2d 1240, 1247 (11th Cir. 1983); United States v. Bohonus, 628 F.2d 1167, 1172 (9th Cir.), cert. denied, 447 U.S. 928 (1980).

33. United States v. Rasheed, 663 F.2d 843, 850 (9th Cir. 1981), cert. denied, 454 U.S. 1157 (1982); United States v. Buchanan, 633 F.2d 423, 427 (5th Cir. Unit A 1980), cert. denied, 451 U.S. 912 (1981).

34. United States v. Lemm, 680 F.2d 1193, 1205 (8th Cir. 1982) (success of scheme not element of $\S 1341$ offense), cert. denied, 459 U.S. 1110 (1983); United States v. Reicin, 497 F.2d 563, 571 (7th Cir.) (same), cert. denied, 419 U.S. 996 (1974).

35. United States v. Bohonus, 628 F.2d 1167, 1172 (9th Cir.) (quoting Irwin v. United States, 338 F.2d 770, 773 (9th Cir. 1964), cert. denied, 381 U.S. 911 (1965)), cert. denied, 447 U.S. 928 (1980).

36. United States v. Brien, 617 F.2d 299, 311 (1st Cir.), cert. denied, 446 U.S. 919 (1980); Lemon v. United States, 278 F.2d 369, 373 (9th Gir. 1960).

37. United States v. Williams, 728 F.2d 1402, 1404 (11th Cir. 1984); United States v. Gelb, 700 F.2d 875,879 (2d Cir.), cert. denied, 464 U.S. 853 (1983). Although there must be a specific intent to defraud, there need not be a specific intent to use the mails. United States v. Cusino, 694 F.2d 185, 188 (9th Cir. 1982) ( $\$ 1343$ case), cert. denied, 461 U.S. 932 (1983).

38. United States v. Schaflander, 719 F.2d 1024, 1027 (9th Cir. 1983), cert. denied, 467 U.S. 1216 (1984); United States v. Boyer, 694 F.2d 58, 59 (3d Cir. 1982).

39. United States v. Kreimer, 609 F.2d 126, 128 (5th Cir. 1980); United States v. Precision Medical Laboratories, Inc., 593 F.2d 434, 443 (2d Cir. 1978); see also Windsor v. United States, 384 F.2d 535, 536-37 (9th Cir. 1967) (actual, rather than constructive, knowledge required); United States v. Interstate Eng'g Corp., 288 F. Supp. 402, 412 (D.N.H. 1967) (judge instructing jury that civil agency 
the basis of mail fraud claims must be material, ${ }^{40}$ but one court has defined materiality as "hav[ing] a natural tendency to influence or . . . capable of influencing another's decision." of the mail fraud statute has significantly expanded the class of activities prohibited by the rules of common law fraud. ${ }^{42}$

Furthermore, at least until the Sedima decision, ${ }^{\mathbf{4 3}}$ any two mailings, even of duplicate material, arising out of the same fraudulent scheme satisfied the "pattern" requirement of a RICO charge," though at least one court disapproved of this multiplication of counts to achieve extra indictments. ${ }^{45}$ Thus, a mail fraud-based RICO claim could be quite simple. It could consist of: (1) The defendant recklessly failed to state a fact which might have deceived someone; (2) in furtherance of this deception, the defendant sent two mailings; and (3) this fraud injured plaintiff's business or property. This simple allegation can result in treble damages for the plaintiff. ${ }^{46}$

\section{RICO's Threat to Patent Holders}

In order to understand how the disclosure requirements of the patent laws might give rise to a mail fraud-based RICO claim, it is necessary to understand the nature of these requirements and their relationship to the law of fraud. Contemporary rules regarding incomplete or false disclosures before the Patent \& Trademark Office (PTO), known as inequitable

principles cannot be used to impute knowledge in mail fraud prosecution).

40. United States v. Haibert, 640 F.2d 1000, 1008 (9th Cir. 1981).

41. United States v. Halbert, 712 F.2d 388, 390 ( 9 th Cir. 1983) (quoting instructions of trial judge), cert. denied, 465 U.S. 1005 (1984); $c f$. TSC Indus. v. Northway, Inc., 426 U.S. 438 (1976) (defining "material" in securities fraud context); United States v. Chandler, 752 F.2d 1148, 1151 (6th Cir. 1985) (same for false statement statute).

42. See Hurson, Limiting the Federal Mail Fraud Statute-A Legislative Approach, 20 AM. Grim. L. Rev. 423, 424 (1983) (in recent years statute "has been expansively interpreted to invite federal prosecution of virtually every type of untoward activity known to man"); Rakoff, supra note 22 , at 772 (characterizing mail fraud statute as "the sole instrument of justice that could be wielded against the ever-innovative practitioners of deceit").

43. For the position of the courts since Sedima, see infra notes 117-21 and accompanying text.

44. United States v. Weatherspoon, 581 F.2d 595, 602 (7th Gir. 1978); United States v. Zang, 703 F.2d 1186, 1194 (10th Cir. 1982), cert. denied, 464 U.S. 828 (1983). In Weatherspoon the defendant argued that all the predicate mailings were in furtherance of the same scheme to defraud and therefore constituted only one act of racketeering activity. 581 F.2d at 601. The Seventh Circuit disagreed and noted that several courts have held that the "pattern" must consist of "acts [that are] connected by a common scheme, plan or motive." Id. at 601-02 \& n.2. This holding is in accordance with the modern trend in federal mail fraud law which locates the crime in the mailing (a necessary jurisdictional component) and not in the scheme to defraud. See supra note 22 and accompanying text. However, even the Seventh Circuit will no longer let the breadth of mail fraud law create inappropriate RICO charges. See infra note 121.

45. United States v. Joyce, 499 F.2d 9, 23 (7th Cir.), cert. denied, 419 U.S. 1031 (1974); 499 F.2d at 25 (Swygert, C.J., dissenting in part).

For the change in approach since Sedima, see infra notes 117-21 and accompanying text.

46. 18 U.S.C. § 1964(c) (1982). 
conduct, developed from both principles of equity and the relaxation of common law fraud rules. ${ }^{47}$ It is this second strand that potential RICO claimants seek to exploit.

\section{A. Patent Law Duty To Reveal Prior Art}

During the last fifteen years, defendants to patent infringement suits have increasingly contested the enforceability of the patent in suit by alleging "inequitable conduct," or, if the conduct is more egregious, contesting validity ${ }^{\mathbf{4 8}}$ by alleging "fraud on the PTO."49 These equitable defenses derive from the duty of the patent applicant to provide to the PTO, with the highest degree of candor, ${ }^{\text {b0 }}$ all known material information on such items as previous related patents, similar inventions, and related documents so that the PTO may properly evaluate the strength of the pending application.. ${ }^{\text {s1 }}$ Such information is known as "prior

47. See Digital Equip. Corp. v. Diamond, 653 F.2d 701, 708 (1st Cir. 1981) ("The concept of 'fraud on the Patent Office,' as something distinct from common law fraud or deceit, derives primarily from judicial opinions in infringement actions, holding patents 'unenforceable' on equitable grounds.").

48. For a discussion of the criteria that can be used to distinguish levels of conduct and of the distinctions between invalidity and unenforceability, see infra Section II.C.

49. " 'Fraud in the PTO' has been over-played, is appearing in nearly every patent suit, and is cluttering up the patent system." Kimberly-Clark Corp. v. Johnson \& Johnson, 745 F.2d 1437, 1454 (Fed. Cir. 1984); see also Preemption Devices, Inc. v. Minnesota Mining \& Mfg. Co., 732 F.2d 903, 908 (Fed. Cir. 1984) (fraud a "much-abused and too often last-resort allegation"); Comment, supra note 8, at 151 (noting popularity of defense).

Throughout this Note, fraud and inequitable conduct will be considered defenses to actions by patentees for infringement. However, these issues can be, and often are, raised by private parties challenging either the validity or enforceability of a patent ("non-patentees") via a declaratory judgment action or suit for refund of royalty payments. The United States can also raise these issues in an action to revoke a patent, although such actions have been rare in the past 25 years. See, e.g., United States v. American Bell Tel. Co., 128 U.S. 315 (1888) (involving original Bell telephone patents); United States v. Standard Elec. Time Co., 155 F. Supp. 949 (D. Mass. 1957). This Note will not consider suits by the United States and will encompass both offensive and defensive charges when using the term inequitable conduct "defenses."

50. KangaROOS U.S.A., Inc. v. Caldor, Inc., 585 F. Supp. 1516, 1522 (S.D.N.Y. 1984) (quoting Kingsland v. Dorsey, 338 U.S. 318, 319 (1949) (per curiam) (attorney barred from Patent Office practice for lack of candor)), vacated and remanded on other grounds, 778 F.2d 1571 (Fed. Cir. 1985).

51. The nature of the equitable defenses is also a result of their long and complex history. An introduction to this history will illuminate more completely the basis for the present structure. In the first modern case of patent fraud, Precision Instrument Mfg. Co. v. Automotive Maintenance Mach. Co., 324 U.S. 806 (1945), the defendant in a patent infringement and contract action raised the equitable defense of "unclean hands." Id. at 807-08. The defendant did not ask to cancel or annul the patent, which, at that time, only the government could do. Mowry v. Whitney, 81 U.S. (14 Wall.) 434 (1872). The defendant in Precision Instrument asserted only that unclean hands prevented enforcement of a patent in a court of equity, and the Supreme Court agreed. It held that equity "does require that [patent holders] shall have acted fairly and without fraud or deceit as to the controversy in issue," 324 U.S. at $814-15$, but that

one's misconduct need not necessarily have been of such a nature as to be punishable as a crime or as to justify legal proceedings of any character. Any willful act concerning the cause of action which rightfully can be said to transgress equitable standards of conduct is sufficient cause for the invocation of the maxim by the chancellor. 
art." 152 Courts imposed the duty of disclosure on applicants to redress the imbalance resulting from the ex parte nature of the patent application process, ${ }^{53}$ where

[b]ecause of limitations on the time and facilities available to the PTO to search for prior art relevant to pending applications for patent, or to conduct tests to check assertions of efficacy or superiority, the PTO must rely heavily on the representations of patent applicants. ${ }^{54}$

Furthermore, the courts reasoned, an applicant may perform this duty with little extra effort because she must provide only information actually known to her. ${ }^{55}$ The PTO has expanded this duty with regulations on the

Id. at 815 (emphasis added). Even so, in agreeing with the defendant, the Court characterized the plaintiff's conduct as "perjury." Id. at 816. The Court also explained why inequitable conduct could affect a patent holder's rights: "The far-reaching social and economic consequences of a patent . . . give the public a paramount interest in seeing that patent monopolies spring from backgrounds free from fraud or other inequitable conduct and that such monopolies are kept within their legitimate scope." Id.

Twenty years later the Court examined the effect of "intentional fraud" during the patent application process and held that such conduct may expose a patent holder to antitrust liability as long as the relevant market allegations are proven. Walker Process Equip., Inc. v. Food Mach. \& Chem. Corp., 382 U.S. 172, 176 (1965). The Court restricted its holding to such grievous conduct, see id. at 179-80 (Harlan, J., concurring) ("knowing and willful fraud"), and held that "good faith," including an "honest mistake," was a complete defense. Id. at 177; see also E.I. du Pont de Nemours \& Co. v. Berkley \& Co., 620 F.2d 1247, 1273 (8th Cir. 1980) ("attempt to base . . . antitrust counterclaim on 'inequitable conduct' has no basis in law").

The Court of Customs and Patent Appeals (CCPA), one predecessor court of the Court of Appeals for the Federal Circuit (CAFC), comprehensively examined the state of patent fraud law in 1970. Norton v. Curtiss, 433 F.2d 779 (C.C.P.A. 1970). Unfortunately, it had no clear analytical framework and intermingled concepts of fraud with concepts of the less exacting "unclean hands" doctrine. See id. at 793. Nevertheless, its holdings have been very influential, in part because all patent appeals are now adjudicated in the CAFC, which derives its precedent from the CCPA. South Corp. v. United States, 690 F.2d 1368, 1369 (Fed. Cir. 1982). The CCPA noted that, traditionally, fraud sufficient to cause cancellation of a patent must approximate common law fraud. Norton, 433 F.2d at 792 . However, the CCPA agreed with other courts that sufficiently "reprehensible" conduct, even though lacking one or more elements the common law would consider necessary to classify the activity as fraudulent, could result in patent unenforceability. Id. at 793; $c f$. infra note 60 (present view on relationship between common law and patent fraud). In doing so, the court liberalized the concept of fraud to encompass the equitable notions of the "unclean hands" doctrine.

Recently, the CAFC has abandoned the term "fraud" and now considers all such claims under the "inequitable conduct" rubric. See infra note 75 and accompanying text.

See generally Miller, Fraud on the PTO, 58 J. PAT. OfF. Soc'y 271 (1976); Comment, supra note 8.

52. See 35 U.S.C. $\S 103$ (1982 \& Supp. III 1985) (obviousness defined with respect to "prior art"); see also infra note 57 (citing sources for prior art definitions).

53. KangaROOS U.S.A., Inc. v. Caldor, Inc., 585 F. Supp. 1516, 1522 (S.D.N.Y. 1984) (quoting Norton v. Curtiss, 433 F.2d 779, 793-94 (C.C.P.A. 1970)), vacated and remanded on other grounds, 778 F.2d 1571 (Fed. Cir. 1985).

54. KangaROOS, 585 F. Supp. at 1522.

55. American Hoist \& Derrick Co. v. Sowa \& Sons, Inc., 725 F.2d 1350, 1362 (Fed. Cir.) (applicant has no duty to search and no obligation to present PTO with information of which she "reasonably should be aware"), cert. denied, 469 U.S. 821 (1984). 
"duty of disclosure."

However, even an applicant acting in good faith may be reluctant to provide material which she believes is either irrelevant or not prior art as the law defines that term, ${ }^{57}$ because an examiner may misinterpret such an admission as providing relevant prior art and therefore reject the application. ${ }^{58}$ Moreover, even a patent applicant who would choose disclosure in all possible cases will still be forced to make innumerable choices regarding potential disclosures. For example, a chemist who invents a new chemical compound cannot possibly provide the PTO with each of the hundreds of documents on chemistry that she read relating to the functional properties of the new compound, even though all chemistry is interrelated and therefore arguably relevant to the patentability decision. Indeed, when applicants have tried to supply all possibly relevant documents to the PTO, parties opposing the patent grant ("non-patentees") have successfully accused them of hiding the most important art by burying it within more trivial information. ${ }^{38}$ Hence, as long as a non-patentee can prove the admissibility and relevance of prior art known to the patentee that was not revealed during the original examination, she has grounds for a fraud or inequitable conduct defense.

\section{B. Relaxation of the Patent Fraud Standard}

Modern courts view the consequences of a successful patent fraud defense as limited to the enforceability of the patent under review, and they do not consider an allegation of patent fraud as a criminal proceeding subject to the normal constitutional, statutory, and judicially-created safeguards. Without the influence of these factors, courts could ignore the consequences of relaxing many of the requirements of common law fraud in the patent context. ${ }^{60}$ This development has in many ways paralleled the

56. See 37 C.F.R. $§ 1.56$ (1986) (original applications); id. $\$ 1.555$ (reexamination proceedings). The PTO enacted the first regulation on the duty to disclose as Rule 56 in 1977.42 Fed. Reg. 5593 (1977). A prior incarnation, entitled "Improper Applications," dates back at least to 1925. The duty is separately applicable to PTO practitioners. 37 C.F.R. $\$ 10.23$ (1986).

57. The categories of prior art are set forth in 35 U.S.C. $\$ \S 102-103$ (1982 \& Supp. III 1985); see also Hazeltine Research, Inc. v. Brenner, 382 U.S. 252 (1965) (exploring meaning of prior art under $\S 103$ ).

58. Cf. Comment, supra note 8, at 161 (present patent fraud standards will induce cautious patent attorneys to disclose excessive information).

59. E.g., Rohm \& Haas Co. v. Crystal Chem. Co., 722 F.2d 1556, 1564 \& n.5, 1573 (Fed. Cir. 1983) (presentation of voluminous documentation in attempt to cure misrepresentation without precise delineation of misrepresentations and curing documents insufficient), cert. denied, 469 U.S. 851 (1984).

60. "[C]onduct before the PTO which may render a patent unenforceable is broader than the common law tort of fraud." Argus Chem. Corp. v. Fibre Glass-Evercoat Co., 759 F.2d 10, 14 (Fed. Cir.), cert. denied, 106 S. Ct. 231 (1985); see also American Hoist \& Derrick Co. v. Sowa \& Sons, Inc., 725 F.2d 1350, 1363-64 (Fed. Cir.) (patent fraud and inequitable conduct requires materiality and intent, not the six elements of common law fraud), cert. denied, 469 U.S. 821 (1984). 
development of mail fraud analysis. ${ }^{61}$ Courts hoped that holding applicants liable for even small infractions would be fairer to non-patentees (thereby enveloping the "unclean hands" doctrine) ) $^{62}$ and would promote candor and good faith disclosure before the PTO. ${ }^{63}$

Presently, nondisclosures as well as misrepresentations may constitute patent fraud or inequitable conduct. ${ }^{64}$ The test for the necessary level of materiality has undergone a considerable evolution. Originally, an objective test required that a "reasonable examiner" would not have allowed the claims but for the misrepresentation. ${ }^{65} \mathrm{~A}$ second test, considering the responses of the actual examiner, was added to increase the number of situations in which the PTO could label a nondisclosure material, and then a third test required only that a reasonable examiner would be influenced in his decision by the misrepresentation. ${ }^{66}$ Now a fourth test has been added, ${ }^{67}$ which is satisfied if a reasonable examiner would merely consider the misrepresentation important in her decision. ${ }^{68}$ Hence, many previously non-material nondisclosures are now material.

The element of intent, which once required willfulness, can now be satisfied by conduct that is reckless or grossly negligent, and such gross negligence may be implied whenever a reasonable person would consider the information material. ${ }^{60}$ In fact, materiality and intent are now balanced by the courts, and a finding of a low level of one may be overcome by a higher level of the other. ${ }^{70}$

The reliance requirement has been subsumed within the materiality test. Moreover, the statement or omission may relate only to claims re-

61. See supra notes $30-42$ and accompanying text.

62. See Precision Instrument Mfg. Co. v. Automotive Maintenance Mach. Co., 324 U.S. 806, 814-16 (1945).

63. See, e.g., American Hoist \& Derrick Co. v. Sowa \& Sons, Inc., 725 F.2d 1350, 1363 (Fed. Cir.), cert. denied 469 U.S. 821 (1984).

64. J.P. Stevens \& Co. v. Lex Tex Ltd., 747 F.2d 1553, 1559 (Fed. Cir. 1984), cert. denied, 106 S. Ct. 73 (1985).

65. Norton v. Curtiss, 433 F.2d 779, 794-95 (C.C.P.A. 1970).

66. J.P. Stevens, 747 F.2d at 1559.

67. Id.

68. Id. The PTO promulgated the fourth test as a rule governing patent applicants, 37 C.F.R. $\S$ 1.56(a) (1986), but it has been uniformly adopted by the courts as a standard of equitable conduct, see In re Jerabek, 789 F.2d 886, 890 n.10 (Fed. Cir. 1986) (affirming denial of reissue patent for violation of Rule 56), in part because the PTO said at the time of its promulgation that the rule merely codified existing judicial precedent on the duty to disclose. 42 Fed. Reg. 5589-90 (1977); see also KangaROOS U.S.A., Inc. v. Caldor, Inc., 778 F.2d 1571, 1576 (Fed. Cir. 1985) (irrelevant whether examiner failed to make appropriate examinations which would have uncovered inequitable conduct).

69. "A permissible finding of gross negligence is sufficient [to prove the requisite intent] and can be shown where appellant's attorney knew or should have known that the withheld reference would be material to the PTO's consideration." Jerabek, 789 F.2d at 891 (citing Driscoll v. Cebalo, 731 F.2d 878, 885 (Fed. Cir. 1984)); see also J.P. Stevens, 747 F.2d at 1560 (same rule applied as part of defense of "fraud on the PTO").

70. The CAFC first set forth the balancing test in American Hoist \& Derrick Co. v. Sowa \& Sons, Inc., 725 F.2d 1350, 1364 (Fed. Gir.), cert. denied, 469 U.S. 821 (1984). 
jected by the PTO or abandoned before decision on the merits, ${ }^{71}$ in which case there really has been no meaningful reliance at all. Injury is presumed. ${ }^{72}$

\section{The Three Levels of Inequitable Conduct}

Prior to the formation of the Court of Appeals for the Federal Circuit (CAFC), most courts separated the types of "inequitable" activity into three levels marked by the consequences imposed..$^{73}$ However, the CAFG, charged with judicial review of PTO decisions and the uniform application of the patent laws, ${ }^{\mathbf{7 4}}$ has taken the strongest stance against dishonesty in the PTO by collapsing "fraud" into "inequitable conduct"75 and ignoring the effects of the various levels of egregiousness of conduct. ${ }^{76}$ Even so, their separate study aids an analysis of the proper application of civil RICO to patent fraud.

Inequitable conduct, which is the least egregious and has traditionally resulted in unenforceability of the patent ${ }^{77}$ is the charge when a patent claim is tainted by misrepresentations or nondisclosures that are either not vital to the claims or not made or omitted willfully. ${ }^{78}$ In theory, unenforceability is curable after corrective disclosures. ${ }^{79}$ The second level, the

71. Driscoll v. Cebalo, 731 F.2d 878, 885 (Fed. Cir. 1984).

72. "Where fraud is committed, injury to the public through a weakening of the Patent System is manifest." Norton v. Curtiss, 433 F.2d 779, 796 (C.C.P.A. 1970). The court holds that injury is to be inferred from a finding of fraud, even though the common law held that proof of fraud requires a finding of injury! Yet the Norton ruling has never been questioned and is often not even discussed. See, e.g., J.P. Stevens, 747 F.2d at 1560.

73. See J.P. Stevens, 747 F.2d at 1560 \& n.7; see also E.I. du Pont de Nemours \& Co. v. Berkley \& Co., 620 F.2d 1247, 1273-74 (8th Cir. 1980) (discussing consequences of various types of conduct); cf. Timely Prods. Corp. v. Arron, 523 F.2d 288, 297-98 (2d Cir. 1975) (recognizing distinctions but arguing irrelevant in this case).

74. S. ReP. No. 275, 97th Cong., 1st Sess. 5-6 (1981), reprinted in 1982 U.S. Code ConG. \& Admin. News 11, 15-16.

75. Argus Chem. Corp. v. Fibre Glass-Evercoat Co., 759 F.2d 10, 12 n.3 (Fed. Cir.), cert. denied, 106 S. Ct. 231 (1985). However, even the CAFC occasionally recognizes that different levels of materiality and intent may have different consequences. See, e.g., Litton Indus. Prods., Inc. v. Solid State Sys. Corp., 755 F.2d 158, 166-67 \& nn.18-19 (Fed. Cir. 1985) (suggesting in dicta that offensive and defensive uses of inequitable conduct cannot be supported by equivalent levels of conduct).

76. See Thompson-Hayward Chem. Co. v. Rohm \& Haas Co., 745 F.2d 27, 33 (Fed. Cir. 1984) (doubting existence of useful difference between unenforceability and invalidity); American Hoist \& Derrick Co. v. Sowa \& Sons, Inc., 725 F.2d 1350, 1364 n.5 (Fed. Cir.) (leaving resolution of this issue for another case), cert. denied 469 U.S. 821 (1984).

77. J.P. Stevens \& Co. v. Lex Tex Lid., 747 F.2d 1553, 1560-61 (Fed. Cir. 1984), cert. denied, 106 S. Ct. 73 (1985). But see supra note 76 (recent CAFC decisions suggest all inequitable conduct sanctions equivalent).

78. E.I. du Pont de Nemours \& Co. v. Berkley \& Co., 620 F.2d 1247, 1274 (8th Cir. 1980) (Markey, C.J. of the CCPA, sitting by designation); see also Kayton, Lynch \& Stern, Fraud in Patent Procurement: Genuine and Sham Charges, 43 Geo. WASH. L. REv. 1, 30-47 (1974) (discussing elements of fraud and inequitable conduct defenses).

79. KangaROOS U.S.A., Inc. v. Caldor, Inc., 585 F. Supp. 1516, 1523 (S.D.N.Y. 1984) (unenforceable patent may be cured-i.e., become enforceable-by cessation of misconduct or reissue), vacated and remanded on other grounds, 778 F.2d 1571 (Fed. Cir. 1985); accord Connell v. Sears, 
type traditionally denominated by "fraud," has required more materiality and/or higher intent. The sanction for fraud is incurable invalidation of the patent. ${ }^{80}$ Not all fraud is treated equally, however. Only misrepresentations or omissions that are both willful and highly material invalidate the patent and revoke the usual exemption granted a patent monopoly holder against antitrust liability. ${ }^{\mathbf{8 1}}$

The Supreme Court in Walker Process Equipment, Inc. v. Food Machinery $\mathcal{E}^{2}$ Chemical Corp. ${ }^{\mathbf{8 2}}$ limited antitrust liability to this last portion of patent applicants because of several policies embedded in the patent law. Though the Court recognized that the public interest in the integrity of patent monopolies required redress for acts of willful and highly material fraud, ${ }^{83}$ it also wanted to shield patentees from "innumerable vexatious suits" that might deter vigorous pursuit of invention. ${ }^{84}$ Justice Harlan's concurrence also emphasized the careful balance protected by the Court between encouraging invention and disclosure and discouraging harmful monopolization. ${ }^{8 s}$ A broader ruling, he warned, "might well chill

Roebuck \& Co., 722 F.2d 1542, 1550 n.1 (Fed. Cir. 1983); Warner-Jenkinson Co. v. Allied Chem. Corp., 477 F. Supp. 371, 394 n.86 (S.D.N.Y. 1979) (reapplication not barred by unenforceable patent under statutory scheme at that time), affd without opinion, 633 F.2d 208 (2d Cir. 1980).

However, the GAFC has now sharply questioned the existence of the possibility of cure. J.P. Stevens, 747 F.2d at 1560 . Even if cure is possible, in practice curing an unenforceable patent is an almost insuperable obstacle. See generally Rohm \& Haas Co. v. Grystal Chem. Co., 722 F.2d 1556, 1571-72 (Fed. Cir. 1983) (discussing extensive corrective measures necessary to overcome prior misconduct), cert. denied, 469 U.S. 851 (1984).

80. But see supra note 76 (recent CAFC decisions suggest all inequitable conduct sanctions equivalent).

Determinations of unenforceability and invalidity affect the entire patent, not just the claim(s) in suit. J.P. Stevens, 747 F.2d at 1561-62, and cases collected in 4 D. Chisum, PATENTs $§ 19.03[6]$, at $19-85$ n.10 (1986); see also 35 U.S.C. $\$ 288$ (1982) (abrogating common law rule that invalidated entire patent whenever one claim invalidated, except in case of fraud). These dire consequences may explain why the standard of persuasion of patent fraud or inequitable conduct is the exacting "clear and convincing evidence." Environmental Designs, Lid. v. Union Oil Co. of Cal., 713 F.2d 693, 698 (Fed. Cir. 1983), cert. denied, 464 U.S. 1043 (1984); see United States v. American Bell Tel. Co., 167 U.S. 224, 241, 251 (1897).

81. Cataphote Corp. v. DeSoto Chem. Coatings, Inc., 450 F.2d 769, 772-73 (9th Cir. 1971), cert. denied, 408 U.S. 929 (1972); Papst Motoren GMbH \& Co. v. Kanematsu-Goshu (U.S.A.) Inc., 629 F. Supp. 864, 870 (S.D.N.Y. 1986) (quoting Erie Technological Prods., Inc. v. JFD Elecs. Components Corp., 198 U.S.P.Q. (BNA) 179, 185 (E.D.N.Y. 1978)); see also Walker Process Equip., Inc. v. Food Mach. \& Chem. Corp., 382 U.S. 172 (1965) (establishing principle of potential antitrust liability); id. at 179-80 (Harlan, J., concurring) (antitrust claims require "knowing and willful fraud"); American Hoist, 725 F.2d at 1368 (for antitrust claim based on patent fraud, court "emphasize[s] that a specific intent, greater than an intent evidenced by gross negligence or recklessness, is an indispensable element"); E.I. du Pont de Nemours \& Co. v. Berkley \& Co., 620 F.2d 1247, 1273 (8th Cir. 1980) ("attempt to base . . . antitrust counterclaim on 'inequitable conduct" has no basis in law"); cf. 15 U.S.C. $§ 14$ (1982) and 35 U.S.C. $\$ 211$ (1982) (sole supplier arrangements of goods, "patented or unpatented," illegal). Of course, even after showing Walker Process fraud, an antitrust plaintiff must still prove the market elements of a monopolization claim. Walker Process, 382 U.S. at 177-78.

82. 382 U.S. 172 (1965).

83. Id. at $176-77$.

84. Id. at 176 .

85. Id. at 179-80 (Harlan, J., concurring). 
the disclosure of inventions through the obtaining of a patent because of fear of the vexations or punitive consequences of treble-damage suits. ${ }^{\prime 86}$

\section{Potential Application of RICO to Patent Suits}

Several practitioners have encouraged non-patentees to bring RICO suits against patent holders. ${ }^{87}$ These commentators have not resolved the important policy questions that underlie the expansion of RICO to patent law; ${ }^{88}$ rather, they argue from analogous cases ${ }^{89}$ that RICO claims not only are easy to add once inequitable conduct is alleged but also may provide treble damages. ${ }^{30}$ The threat of substantial recovery would be a powerful negotiating edge against a patent holder who may be contemplating her own treble damages suit against the non-patentee for infringement. ${ }^{91}$

A non-patentee can easily transform an inequitable conduct defense into a RICO claim. Most communication with the PTO occurs via the mails and the wires. ${ }^{22}$ Each mailing, telephone call, or use of a means of electronic communication becomes a separate predicate act because it furthers the alleged inequitable conduct. If the courts, like many commentators, ignore the crucial and often subtle distinctions between criminal fraud and inequitable conduct, any two such acts would thus suffice to ground a RICO claim. In that case, the protection from vexatious lawsuits so carefully provided by Walker Process would be obliterated. Indeed, RICO claims are much simpler to add to patent defenses than antitrust claims, requiring few allegations beyond two mailings and gross negligence.

86. Id. at 180 (Harlan, J., concurring) (emphasis added).

87. See, e.g., J. Fricano, Guide to RICO 50 (BNA Corporate Practice Series 1986); Adamo \& Ducatman, supra note 20; see also Coolley, RICO: Modern Weaponry Against Software Pirates, 5 COMPuTER L.J. 143 (1984) (argument by analogy); Coolley, RICO: A New Weapon in Intellectual Property Law, 66 J. PAT. OfF. Soc'y 138 (1984) (same). At least four patent RICO cases have been instituted, but none has prompted a decision on the merits. Carpenter Technology Corp. v. Armco Inc., No. 86 Civ. 608 (MJL) (S.D.N.Y. Apr. 1, 1986) (LEXIS, Genfed library, Dist file) (RICO counts dismissed due to prior settlement); see Adamo \& Ducatman, supra note 20, at 188 n.8 (noting three cases).

88. See infra notes $93-114$ and accompanying text.

89. See, e.g., Adamo \& Ducatman, supra note 20 , at 187 \& n.6. For examples of cases in related fields, see Conan Properties, Inc. v. Mattel, Inc., 619 F. Supp. 1167 (S.D.N.Y. 1985) (copyright); Soltex Polymer Corp. v. Fortex Indus., 590 F. Supp. 1453 (E.D.N.Y. 1984) (trademark).

90. See supra text accompanying notes 14-15; see also Sedima, S.P.R.L. v. Imrex Co., 105 S. Ct. 3275, 3288 n.2 (1985) (Powell, J., dissenting) (noting lure to plaintiffs of treble damages recovery).

91. 35 U.S.C. $\S 284$ (1982) authorizes recoveries for infringement of amounts not exceeding three times the damages sustained.

92. See, e.g., Patent \& Trademark Office, U.S. DeP't of Commerce, Manual of Patent ExAmining Procedure $\S \S 713-713.10$ (1983) (procedures for communications between PTO and applicants); id. $\S \S 501-513$ (receipt and handling of papers by mail and other means). 


\section{Inappropriateness of Rico in Most Patent Fraud Cases}

Civil RICO allegations should not be permitted in any but the most extreme patent fraud cases, even though a superficial reading of the RICO and mail fraud statutes might indicate the acceptability of a broader use. ${ }^{93}$ The policies that underlie the patent laws, unlike the policies behind the results in business fraud cases, ${ }^{94}$ are sufficiently weighty to demand a re-evaluation of RICO's scope before RICO is extended to include traditional patent fraud. The weight of the patent laws derives from the constitutional duty to "promote the Progress of Science and useful Arts,"98 and from the necessary incentives that patents create for inventors. ${ }^{86}$ Close scrutiny of these policies demonstrates that in the absence of willfulness and high materiality patent fraud does not give rise to RICO liability.

93. The article by Adamo \& Ducatman, supra note 20 , is at present the only published work to discuss in detail the application of civil RICO to inequitable conduct before the PTO. The authors conclude with a plea that patent RICO claims "should not and must not become part of the same boilerplate, knee-jerk charges of fraud and inequitable conduct that seem to find their way into every answer filed in every patent infringement case." Id. at 247 . Unfortunately, they could find no legal barriers to RICO claims: "There appears to be no theoretical or policy justification grounded in the patent laws for denying the addition of a RICO-based claim to the arsenal of recognized patentrelated defenses and offenses." Id. at 187 . At most they argue that the very low levels of materiality and intent that invalidated the patent application in Driscoll v. Cebalo, 731 F.2d 878 (Fed. Cir. 1984), "plainly should not be sufficient" to support a patent RICO claim because extension of mail fraud and RICO to such conduct is "too attenuated." Adamo \& Ducatman, supra note 20, at 230.

This plea for restraint and lack of argument is no longer enough. First, more recent opinions of the CAFC make clear that the balancing test of American Hoist, not the more expansive rule of Driscoll, is the primary tool for determining inequitable conduct. See, e.g. KangaROOS U.S.A., Inc. v. Caldor, Inc., 778 F.2d 1571, 1573 (Fed. Cir. 1985). Hence Driscoll-type conduct, which still may prevent patent issuance under Rule 56, should no longer support a mail fraud charge. $C f$. State Indus. v. Rheem Mfg. Co., 769 F.2d 762 (Fed. Cir. 1985) (no inequitable conduct where nondisclosure not material and patentee at most grossly negligent). Moreover, policy arguments provide a more complete demonstration of the insufficiency of the Adamo \& Ducatman conclusions. The same analysis that formed the basis of the opinions in Walker Process requires that judges limit RICO claims to patent fraud grevious enough to create potential antitrust liability.

94. Careful control of the entire patent system has been an objective of Congress since the founding of the nation. See infra note 95 and accompanying text (discussing constitutional basis of patent laws); see also Grant v. Raymond, 31 U.S. (6 Pet.) 218, 241 (1832) (Marshall, C.J.) ("II]t cannot be doubted that the settled purpose of the United States has ever been, and continues to be, to confer on the authors of useful inventions an exclusive right in their inventions . . . ."); Act of April 10, 1790, ch. 7, 1 Stat. 109 (first patent act); Comment, supra note 8, at 159 ("The fundamental purpose of the United States patent system is to stimulate the development of technology . . . .). Congress has shown no corresponding concern for ordinary businessmen.

Moreover, because of the importance of the patent system, the Supreme Court has limited liability in other areas of the law, such as antitrust, to the more egregious levels of patent fraud. See supra text accompanying notes 83-86. By contrast, the Supreme Court has often extended the liability for "garden variety" commercial fraud. E.g., TSC Indus. v. Northway, Inc., 426 U.S. 438 (1976) (extending liability under SEC Rule 14a-9); Sedima, S.P.R.L. v. Imrex Co., 105 S. Ct. 3275 (1985) (RICO).

95. U.S. ConsT. art. I, § 8, cl. 8; see also Kewanee Oil Co. v. Bicron Corp., 416 U.S. 470, 480 (1974) (positive effects of incentives in patent laws create new products and processes which benefit all citizens).

96. See Comment, supra note 8 , at 160 (discussing incentive effects of patent system on inventors). 


\section{A. Limitations from Patent Law}

As presently construed, both ordinary patent fraud and its extreme, Walker Process fraud, fall within the broadly interpreted outlines of the mail and wire fraud statutes and hence within RICO. However, the special nature of the patent laws, recognized in Walker Process, should caution the courts against reflexive application of RICO in this context. Arguments based on policy are especially helpful with a statute like RICO, whose seemingly limitless breadth under literal interpretation has created confusion in the courts ${ }^{97}$ and spurred many calls for reform. ${ }^{88}$ Moreover, unlike ordinary business fraud cases, clear rules for liability based on patent fraud may be proposed that do not conflict with the policies behind RICO.

If the courts do not curb the potential use of civil RICO in patent fraud suits they will discourage invention and the disclosure of inventions in patents, thereby inhibiting the progress of technological advancement. ${ }^{99}$ The balance between encouraging invention with its accompanying disclosure and discouraging abusive market power has been, for the most part, carefully protected by both the courts ${ }^{100}$ and Congress, which, in the past several years, has passed two different statutes, ${ }^{101}$ each designed to increase the protection of patent grants. ${ }^{102}$ Given this special concern for the integrity of the incentives in the patent system, courts should decline to extend RICO to the patent application process, except where patent holders willfully violate their patent "contracts" and remove themselves from the protection of the patent laws. Just as Walker Process ${ }^{103}$ holds that only willful and highly material fraud can strip patent holders of their protection from antitrust liability, only similarly egregious fraud should

97. See, e.g., infra text accompanying notes 120-23.

98. See, e.g., sources cited infra note 116.

99. See supra text accompanying notes 83-86.

100. See, e.g., Walker Process Equip., Inc. v. Food Mach. \& Chem. Corp., 382 U.S. 172 (1965) (protecting most patentees from vexatious antitrust suits); Handgards, Inc. v. Ethicon, Inc., 601 F.2d 986, 992-93 (9th Cir. 1979) (same), cert. denied, 444 U.S. 1025 (1980).

101. Patent Law Amendments Act of 1984, Pub. L. No. 98-622, 1984 U.S. Code Cong. \& Admin. News (98 Stat.) 3383 (expanding protections available to inventors); Federal Courts Improvement Act of 1982, Pub. L. No. 97-164, 96 Stat. 25 (creating CAFC).

102. See, e.g., 130 Cong. Rec. H10,525, H10,527 (daily ed. Oct. 1, 1984), reprinted in 1984 U.S. Code Cong. \& Admin. News 5827, 5833-34; S. ReP. No. 275, 97th Cong., 1st Sess. 5-6 (1981), reprinted in 1982 U.S. CoDE Cong. \& ADMIN. News 11, 15-16.

103. Walker Process Equip., Inc. v. Food Mach. \& Chem. Corp., 382 U.S. 172 (1965). 
create RICO liability. The majority ${ }^{104}$ of inequitable conduct cases would thus fall outside the bounds of RICO. ${ }^{105}$

Courts should also impose a more stringent standard of persuasion ${ }^{108}$ on patent RICO claims than on other RICO claims based on predicate acts of mail fraud. Whereas ordinary civil RICO plaintiffs need only demonstrate the predicate acts by a preponderance of the evidence, ${ }^{107}$ the standard of persuasion of inequitable conduct or fraud during the patent application process is the more exacting "clear and convincing evidence." 108 The higher standard derives from the history of civil fraud claims $^{109}$ and concerns about the drastic consequences ${ }^{110}$ of a finding of patent fraud. ${ }^{111}$ These consequences, along with the need to maintain the proper balance of incentives under the patent system, also motivated the Supreme Court's holding in Walker Process. ${ }^{122}$ Several courts have highlighted these considerations and have required that antitrust claims based on fraudulent infringement actions be proven by clear and convincing evidence, rather than by a preponderance of the evidence-the usual standard for civil antitrust suits. ${ }^{113}$ Courts must retain this balance in the

104. An accurate count of the number of inequitable conduct, fraud, and Walker Process fraud disputes would be difficult, if not impossible, to obtain, especially since most court opinions focus on the problematic cases at the two extremes. Nonetheless, it seems fair to assume that the recommendations set out here will reduce the reach of RICO to a small fraction of all disputes where inequitable conduct or fraud is alleged.

105. Cf. Precision Instrument Mfg. Co. v. Automotive Maintenance Mach. Co., 324 U.S. 806, 815 (1945) (actions that in equity may render patent unenforceable need not be criminal). No cases of criminal patent fraud prosecutions are reported, though the government has occasionally brought civil actions to cancel patents. See supra note 49.

106. For the differences between "burden of proof" and "standard of persuasion," see Note, Causation in Toxic Torts: Burdens of Proof, Standards of Persuasion, and Statistical Evidence, 96 YALE L.J. 376, 380-81 (1986).

107. United States v. Local 560 of Int'l Bhd. of Teamsters, 780 F.2d 267, 279 n.12 (3d Cir. 1985), cert. denied, 106 S. Ct. 2247 (1986). In adopting the preponderance standard in Local 560, the Third Circuit was strongly swayed by Santosky v. Kramer, 455 U.S. 745, 754 (1982) (setting forth three-part balancing test for determining proper standard of persuasion), Herman \& MacLean v. Huddleston, 459 U.S. 375, 389-90 (1983) (rejecting, for securities law Rule 10b-5 cases, common law standard of "clear and convincing evidence" traditionally used in fraud cases, in favor of preponderance standard), and Sedima, S.P.R.L. v. Imrex Co., 105 S. Ct. 3275, 3282-83 (1985) (5-4 decision) (suggesting, without deciding, that preponderance standard may be sufficient in civil RICO actions). Local 560, 780 F.2d at 279 n.12.

108. See supra note 80 .

109. Herman \& MacLean v. Huddleston, 459 U.S. 375, 388 \& n.27 (1983); United States v. American Bell Tel. Co., 167 U.S. 224, 240-42 (1897).

110. Potential consequences include rejection of a patent application, In re Jerabek, 789 F.2d 886 (Fed. Cir. 1986), loss of an interference proceeding, Driscoll v. Cebalo, 731 F.2d 878 (Fed. Cir. 1984), patent unenforceability, J.P. Stevens \& Co. v. Lex Tex Lid., 747 F.2d 1553 (Fed. Cir. 1984), cert. denied, 106 S. Ct. 73 (1985), and disciplinary action for patent counsel, Kingsland v. Dorsey, 338 U.S. 318 (1949) (per curiam); 37 G.F.R. $\$ \S 10.20($ b), 10.23(c)(2), (10), (11) (1986).

111. Norton v. Curtiss, 433 F.2d 779, 797 (C.C.P.A. 1970).

112. See supra text accompanying notes $83-86$.

113. See, e.g., Loctite Corp. v. Ultraseal Ltd., 781 F.2d 861, 876-77 (Fed. Cir. 1985) (applying Seventh Circuit law); Cataphote Corp. v. DeSoto Chem. Coatings, Inc., 450 F.2d 769, 772 (9th Cir. 1971), cert. denied, 408 U.S. 929 (1972). 
RICO context, and the clear and convincing evidence standard should replace the typical civil RICO standard in patent cases. ${ }^{114}$

\section{B. Limitations from RICO}

The special characteristics of a RICO action also place limits on patent RICO claims. The dissenters in Sedima felt that the legislative history of RICO requires that the statute be restricted to organized crime figures and other "racketeers," as opposed to the "legitimate businesses" presently under attack. ${ }^{115}$ Adoption of the minority's position ${ }^{116}$ would have virtually eliminated patent RICO claims. A RICO claimant would have had to prove that an organized crime member fraudulently obtained the patent in furtherance of her criminal activities.

Even under the majority's expansive view of the statute, RICO provides several methods for limiting civil patent RICO claims. For example, the Court in Sedima suggested that the lower courts could narrow the definition of "pattern of racketeering activity."117 This statutory definition is peculiar to RICO because its use of "requires" instead of "means" seems to mandate that the courts add constraints consonant with the rest of the Act. ${ }^{118}$ The Court noted that the legislative history supports the idea that "pattern" implies that the predicate acts must be related to one another and be part of a continuing scheme of activity. ${ }^{119}$

Since Sedima, the lower courts have sharply disagreed on the require-

114. Cf. Santosky v. Kramer, 455 U.S. 745,755 (1982) (constitutionally permissible minimum standard of persuasion reflects weight of public and private interests affected, as well as societal judgment about distribution of risk of error).

115. Sedima, $105 \mathrm{~S}$. Ct. at 3288-89 (Powell, J., dissenting); id. at 3302 (Marshall, J., dissenting); see also 1985 Hearings, supra note 27, at 272-73 (app. to statement of Ray J. Graves, Chairman, AICPA) (partial list of "legitimate" private civil RICO defendants); H.R. REP. No. 1549, 91st Cong., 2d Sess. 187, reprinted in 1970 U.S. CoDE CoNG. \& ADMIN. NEws 4007, 4083 (dissenting views of Reps. Conyers, Mikva, and Ryan) (private action is "invitation for disgruntled and malicious competitors to harass innocent businessmen").

116. The majority suggested that Congress "correct" RICO if unhappy with the course it has taken. Sedima, $105 \mathrm{~S}$. Ct. at 3287 . Though Congress rarely reforms statutes at the Court's suggestion, many voices have joined the Court. E.g., N.Y. Times, Oct. 15, 1985, at D2, col. 1. Several amendments to RICO were introduced in the 99th Congress. H.R. 5445, 99th Cong., 2d Sess. (1986) (passed by House; no vote in Senate); H.R. 4892, 99th Cong., 2d Sess. (1986); H.R. 3985, 99th Cong., 1st Sess. (1985); H.R. 2943, 99th Cong., 1st Sess. (1985); H.R. 2517, 99th Cong., 1st Sess. (1985); S. 1521, 99th Cong., 1st Sess. (1985).

117. Sedima, 105 S. Ct. at 3285 n.14, 3287.

118. See supra note 18 (full text of $\S 1961(5)$ ).

119. Sedima, $105 \mathrm{~S}$. Ct. at 3285 n.14. The Court also suggested that another definition of "pattcrn" contained in the same law, codified at 18 U.S.C. $\S 3575(\mathrm{e})$ (1982) and repealed by Pub. L. No. 98-473, tit. II, ch. II, $\S 212$ (a)(2), 1984 U.S. Code Cong. \& AdmIN. News (98 Stat.) 1837, 1987 (1984) (effective Nov. 1, 1987), may be useful in interpreting RICO. 105 S. Ct. at 3285 n.14; $c$. Superior Oil Co. v. Fulmer, 785 F.2d 252, 257 \& n.7 (8th Cir. 1986) (using, inter alia, $\$ 3575(e)$ to conclude that one fraudulent scheme, even where it may give rise to two predicate acts, does not evince pattern); Foltz v. U.S. News \& World Report, Inc., 108 F.R.D. 57, 60 (D.D.C. 1985) (using principles underlying $\S 3575$ (e) to focus on RICO pattern requirements). 
ments of the "pattern" definition. Some continue to hold that any two acts of mail fraud arising out of a single scheme themselves constitute a pattern. ${ }^{120}$ Other courts adopt a more complex approach to discerning a pattern, emphasizing relatedness and continuity of the predicate acts, the open-ended nature of the criminal conduct, and the similarity of the activity to organized crime. ${ }^{121}$ The latter approach to the pattern requirement is better reasoned because it more closely reflects the plain meaning of the words of the statute as well as the legislative history. ${ }^{122}$ When the explicitly announced elements of a definition do not fully establish all the characteristics of a concept that the plain meaning of its terms imply, it is proper to infer all other elements that complete the intended meaning of the statute. ${ }^{123}$

Adding the implicit elements to the pattern requirement would significantly reduce the number of patent RICO claims, barring most claims found undesirable using the Walker Process analogy. ${ }^{124}$ Most patent fraud suits involve only one application process ${ }^{\mathbf{1 2 5}}$ and one fraudulent scheme. The fraud lasts only until the application process ends. Hence, although each misrepresentation or omission within a single examination might give rise to a separate count of mail or wire fraud, even several counts do not necessarily evince a "pattern." If a RICO allegation involves several claims or several applications for related patents by the same inventor or assigned to the same person, a finding of a pattern is

120. United States v. Ianniello, 808 F.2d 184, 191-93 (2d Cir. 1986); R.A.G.S. Couture, Inc. v. Hyatt, 774 F.2d 1350, 1355 (5th Cir. 1985); LSC Assocs. v. Lomas \& Nettleton Fin. Corp., 629 F. Supp. 979, 981-82 (E.D. Pa. 1986); see also Moran, The Meaning of Pattern in RICO, 62 CHI.KENT L. REv. 139 (1985) (suggesting that relatedness is part of "pattern" but that single scheme may be enough).

This interpretation of pattern is exacerbated by the fact that each use of the mails in a single fraudulent scheme is a separate violation of $\S 1341$, so that there may be no correlation between the number of predicate acts and the egregiousness of the conduct. See supra note 22.

121. Superior Oil Co. v. Fulmer, 785 F.2d 252, 256-57 (8th Cir. 1986) (citing with approval various elements of RICO pattern); Richter v. Sudman, 634 F. Supp. 234, 238-40 (S.D.N.Y. 1986) (focusing on continuity and relatedness); Northern Trust Bank/O'Hare v. Inryco, Inc., 615 F. Supp. 828, 831-33 (N.D. Ill. 1985) (requiring continuity, relatedness, and different criminal episodes separated in time); see also Bank of Am. Nat'l Trust \& Sav. Ass'n v. Touche Ross \& Co., 782 F.2d 966, 971 (11th Cir. 1986) (adopting suggestion of Sedima to use $\S 3575(\mathrm{e})$ to interpret "pattern").

The Seventh Circuit once asserted that any two acts of mail fraud created a pattern. United States v. Weatherspoon, 581 F.2d 595, 601-02 (7th Cir. 1978); see supra note 44. However, the court recently overruled Weatherspoon and chose the "middle course" among post-Sedima opinions, requiring a case-by-case evaluation of continuity and relationship. Morgan v. Bank of Waukegan, 804 F.2d 970, 975 (7th Cir. 1986).

122. See supra note 10 and accompanying text (discussing original purpose of RICO).

123. Cf., e.g., Ernst \& Ernst v. Hochfelder, 425 U.S. 185 (1976) (common meaning of words of 15 U.S.C. $\$ 78 \mathrm{j}(\mathrm{b})$ as well as legislative history suggest that scienter must be implied as part of proper claim under statute).

124. See supra text accompanying notes 99-105.

125. Continuation-in-part and divisional applications are part of the same application process, a fact that Congress recognized when it gave such applications the same filing date as the original. 35 U.S.C. $\$ \S 120-121$ (1982 \& Supp. III 1985). 
more reasonable as well as more consistent with the original conception of RICO as a weapon against large-scale, sophisticated, criminal organizations.

Another possibility for restricting the use of RICO in patent cases focuses on the Act's definition of "person." The "person" who engages in racketeering activity and violates section $1962(c)^{126}$ must be distinct from the "enterprise" that receives the unfair economic advantage. ${ }^{127}$ This distinction is crucial in the patent context because most private-sector inventors assign their patents to corporations, ${ }_{1}^{128}$ and those corporations often represent their assignees in the application process. ${ }^{129}$ Thus the corporations both commit and benefit from the predicate acts. It must be noted, however, that this limitation on RICO pleading applies regardless of the seriousness of the underlying patent fraud.

A final limitation derives from the nature of the relief available under RICO. By itself, patent fraud requires no reliance and injury, because a patent may be rendered unenforceable due to inequitable conduct connected only to a claim in the application that did not become part of the issued patent. ${ }^{130}$ However, RICO's civil action provision requires that a plaintiff be actually injured by the pattern of racketeering activity. ${ }^{131}$ This

126. It is most likely that a patent fraud RICO claim would be brought under $\S 1962(\mathrm{c})$. The broadest provision, $\S 1962$ (c) makes unlawful the conduct of an enterprise through a pattern of racketeering activity. Section 1962(a), on the other hand, requires proof that an enterprise was acquired or maintained with funds derived from the pattern of racketeering activity. In order to obtain such proof, a plaintiff would need to understand the flow of license fees and royalties from a fraudulently obtained patent. Besides, the courts remain divided on the need for pattern/enterprise distinctions in $\S$ 1962(a) cases. See infra note 127. Section 1962(b) seems wholly inapplicable, see supra note 14, and requires the same dichotomy as $\S 1962$ (c). See infra note 127.

127. Schofield v. First Commodity Corp. of Boston, 793 F.2d 28, 29-34 (1st Cir. 1986) ("person" and "enterprise" cannot be identical under either direct or respondeat superior liability); Bennett v. United States Trust Co., 770 F.2d 308, 315 (2d Cir. 1985), cert. denied, 106 S. Ct. 800 (1986); B.F. Hirsch v. Enright Ref. Co., 751 F.2d 628, 633 (3d Cir. 1984); United States v. Computer Sciences Corp., 689 F.2d 1181, 1190-91 (4th Cir. 1982), cert. denied, 459 U.S. 1105 (1983); Bishop v. Corbitt Marine Ways, Inc., 802 F.2d 122 (5th Cir. 1986) (per curiam); Haroco, Inc. v. American Nat'l Bank \& Trust Co., 747 F.2d 384, 399-402 (7th Cir. 1984), affd on other grounds per curiam, $105 \mathrm{~S}$. Ct. 3291 (1985); Bennett v. Berg, 685 F.2d 1053, 1061 (8th Cir. 1982), affd en banc, 710 F.2d 1361, cert. denied, 464 U.S. 1008 (1983); Rae v. Union Bank, 725 F.2d 478, 481 (9th Cir. 1984). Contra United States v. Hartley, 678 F.2d 961, 988-89 (11th Cir. 1982), cert. denied, 459 U.S. 1183 (1983). See generally Adamo \& Ducatman, supra note 20, at $246 \mathrm{nn} .193-94$.

By the same reasoning, the "person" and the "enterprise" must be distinct under $\$ 1962(\mathrm{~b})$. Bruss Co. v. Allnet Communication Servs., Inc., 606 F. Supp. 401, 407 (N.D. Ill. 1985). However, the courts sharply disagree whether they may be the same under $\S 1962(a)$. Compare Masi v. Ford City Bank \& Trust Co., 779 F.2d 397, 401-02 (7th Cir. 1985) (can be identical) and B.F. Hirsch, Inc. v. Enright Ref. Co., 617 F. Supp. 49, 51-52 (D.N.J. 1985) (same) with Rush v. Oppenheimer \& Co., 628 F. Supp. 1188, 1197 (S.D.N.Y. 1985) (must be distinct) and Willamette Sav. \& Loan v. Blake \& Neal Fin. Co., 577 F. Supp. 1415, 1427 (D. Or. 1984) (same).

128. Note, Incentives for People: The Forgotten Purpose of the Patent System, 16 Harv. J. on LEGIS. 129, 155 (1979). 35 U.S.C. § 261 (1982) authorizes the assignment of any application for patent, patent, or interest in a patent.

129. See 37 C.F.R. $\S 1.32$ (1986) (authorizing prosecution by assignee).

130. See supra notes 71-72 and accompanying text.

131. 18 U.S.C. $\S 1964$ (c) (1982). 
limits RICO actions to patents that issue with a fraudulently procured claim. This restriction, like the person/enterprise requirement, is unrelated to the severity of the fraud. Moreover, injunctive relief, which some thought at one time to be within a court's power in private civil RICO actions, ${ }^{132}$ now seems to be unavailable. ${ }^{133}$ The lack of this method of relief in private RICO actions means that plaintiffs may not use civil RICO alone to have patents declared unenforceable or invalid, although a declaratory judgment count ${ }^{\mathbf{1 3 4}}$ can be added to the suit to obtain this relief.

\section{ConClusion}

These substantial limitations will reduce the number of successful patent civil RICO claims, restoring the balance carefully maintained by the existing system of patent laws. However, RICO plaintiffs actually injured by the unfair economic advantage of a defendant's fraudulently procured patents will still be able to recover in a manner consistent with the desires of Congress and the spirit of the statute.

132. Bennett v. Berg, 685 F.2d 1053, 1064 (8th Cir. 1982) (dictum), affd en banc on other grounds, 710 F.2d 1361, cert. denied, 464 U.S. 1008 (1983); Aetna Casualty \& Sur. Co. v. Liebowitz, 570 F. Supp. 908, 910-11 (E.D.N.Y. 1983), affd on other grounds, 730 F.2d 905 (2d Cir. 1984); see also Belgard, Private Civil RICO Plaintiffs Are Entitled to Equitable Relief Under \$ 1964(a), 2 RICO L. REP. 537 (1985). Contra Miller v. Affiliated Fin. Corp., 600 F. Supp. 987, 994 (N.D. Ill. 1984).

133. Religious Technology Center v. Wollersheim, 796 F.2d 1076, 1081-84 (9th Cir. 1986).

134. 28 U.S.C. § 2201 (1982 \& Supp. III 1985); see also Kerotest Mfg. Co. v. C-O-Two Fire Equip. Co., 342 U.S. 180 (1952) (limiting ability of non-patentee to bring declaratory judgment action in forum other than one of existing infringement action). 